\title{
A survey of East Palaearctic Gnaphosidae (Aranei). 9. New data on the Parasyrisca potanini-group from Central Asia
}

\author{
Обзор Gnaphosidae (Aranei) Восточной Палеарктики. 9. Новые \\ данные о группе Parasyrisca potanini Џентральной Азии
}

\author{
Alexander A. Fomichev', Yuri M. Marusil ${ }^{2-4}$,Vladislav V. Sidorov ${ }^{1,5}$ \\ А.А. Фомичев ${ }^{1}$ Ю.М. Марусик ${ }^{2-4}$, В.В. Сидоров ${ }^{1,5}$

\footnotetext{
${ }^{1}$ Altai State University, Lenina Pr., 61, Barnaul, RF-656049 Russia. E-mail: a.fomichov@mail.ru

${ }^{2}$ Institute for Biological Problems of the North, Portovaya Street 18, Magadan 685000 Russia. E-mail: yurmar@mail.ru

${ }^{3}$ Department of Zoology \& Entomology, University of the Free State, Bloemfontein 9300, South Africa.

${ }^{4}$ Zoological Museum, Biodiversity Unit, University of Turku, FI-20014 Turku, Finland.

${ }^{5}$ E-mail: vladsidorov777@gmail.com

${ }^{1}$ Алтайский Государственный Университет, Проспект Ленина, 61, Барнаул, 656049 Россия.

${ }^{2}$ Институт биологических проблем Севера ДВО РАН, Портовая 18, Магадан, 685000 Россия.
}

KEY WORDS: Araneae, ground spiders, Kazakhstan, Mongolia, South Siberia, new species, taxonomy. КЛЮЧЕВЫЕ СЛОВА: Araneae, Казахстан, Монголия, Южная Сибирь, новые виды, систематика.

ABSTRACT: Both sexes of three new species of Parasyriscaare described from Eastern Kazakhstan and Western Mongolia: P. kosachevi sp.n., P. sulaki sp.n., and $P$. tronovorum sp.n. All new species were collected in highlands at elevations from 2700 to $3700 \mathrm{~m}$. The female of $P$. volynkini Fomichev, 2016 from the Altai Mountains (South Siberia, Russia) is described for the first time. Descriptions, differential diagnoses, illustrations, and maps of distribution records are provided. The distribution and species composition of the all four Parasyrisca groups (potanini, vinosa, guzeripli, and breviceps) are discussed.

How to cite this article: Fomichev A.A., Marusik Yu.M., Sidorov V.V. 2018. A survey of East Palaearctic Gnaphosidae (Aranei). 9. New data on the Parasyrisca potanini-group from Central Asia // Arthropoda Selecta. Vol.27. No.2. P.155-168. doi: 10.15298/ arthsel. 27.2.07

РЕЗЮМЕ: Из Восточного Казахстана и Западной Монголии по обоим полам описываются три новых вида: Parasyrisca kosachevi sp.n., P. sulaki sp.n. и $P$. tronovorum sp.n. Все новые виды были собраны в высокогорьях на высотах от 2700 до 3700 м. Впервые описывается самка $P$. volynkini Fomichev, 2016 из Алтайских гор (Южная Сибирь, Россия). Приводятся описания, иллюстрации и карты распространения. Обсуждается объединение видов в группы и распространение всех четырёх групп видов (potanini, vinosa, guzeripli и breviceps).

\section{Introduction}

Parasyrisca Schenkel, 1963 is a Holarctic genus of ground spiders with 52 valid species, 51 distributed in the Palaearctic and one in the Western Nearctic [World Spider Catalog, 2017]. Almost all species inhabit the alpine zone in high mountains. Some species live at very high altitudes, up to $3500 \mathrm{~m}$ in the Caucasus, 3300 $\mathrm{m}$ in South Siberia, and $4900 \mathrm{~m}$ in the Pamirs [Ovtsharenko et al., 1995; Fomichev, 2015]. Moreover two Parasyrisca species are known in the Subarctic (in the Magadan Region) at $63^{\circ} \mathrm{N}$ latitude [Ovtsharenko, Marusik, 1988, 1996]. Only three species are known from lowland or low mountains habitats: P. arrabonica Szinetár et Eichardt, 2009 from Hungary, P. marusiki Kovblyuk, 2003 from Crimea and $P$. golyakovi Marusik et Fomichev, 2016 from the western Altai Mountains (South Siberia). The majority of species are local endemics found only in one mountain range [Ovtsharenko et al., 1995].

Ovtsharenko et al. [1995] assigned all Parasyrisca species into four species groups: potanini, vinosa, guzeripli and breviceps. The most species-rich group, potanini, encompasses 36 species. During expeditions to the Dzhungarian Alatau Mountains in Southeastern Kazakhstan, the Mongolian Altai in Western Mongolia, and the Russian part of the Altai we collected males and females of three undescribed species of Parasyrisca as well as the previously unknown female of $P$. volynkini Fomichev, 2016. The goal of this paper is to describe the three new species and the female of $P$. volynkini. 


\section{Material and methods}

Specimens were photographed at the Zoological Museum (University of Turku, Finland) with a Canon EOS 7D camera attached to an Olympus SZX16 stereomicroscope and at the Institute of Systematics and Ecology of Animals (Novosibirsk, Russia) with an AxioCamMRc 5 (Zeiss) camera attached to a Stemi 2000C stereomicroscope. Digital images were montaged using CombineZP and Helicon focus 3.10 image stacking software. Epigynes were cleared in a $\mathrm{KOH} /$ water solution until soft tissues were dissolved. Photographs were taken in dishes with paraffin on the bottom holding the specimens in position. All measurements are given in millimeters. Lengths of leg segments were measured on the dorsal side. Spination data are based on examination of legs on one side of the body of one specimen of each species. All apical spines on metatarsi III and IV were counted. The format of description and terminology follows Ovtsharenko et al. [1995] and Szinetar et al. [2009] with some modification.

\section{Abbreviations}

Museums: ISEA - Museum of the Institute of Systematic and Ecology of Animals, Novosibirsk, Russia. ZMMU - Zoological Museum of the Moscow State University, Russia.

Leg segments: Fe - femur, Mt - metatarsus, Pt patella, $\mathrm{Ta}$ - tarsus, $\mathrm{Ti}$ - tibia.

Spination: d - dorsal, $\mathrm{p}$ - prolateral, $\mathrm{r}$ - retrolateral, $\mathrm{v}$ - ventral.

\section{Taxonomic survey}

\section{Parasyrisca potanini group}

Parasyrisca potanini group: Ovtsharenko et al., 1995: 5.

DIAGNOSIS. Males belonging to this group can be recognized by the presence of a short, narrow, prolaterally directed embolus, medially or retrolaterally situated on the genital bulb and in close proximity to an elongate, transparent conductor (conductor sometimes absent) and a flat, quadrangular retrolateral tibial apophysis. Females can be recognized by the deep epigynal fovea with a long posterior hood and elongate, curved receptacles that are widened medially or anteriorly [Ovtsharenko et al., 1995].

COMPOSITION. Ovtsharenko et al. [1995] placed 31 species in this group, the majority known from Kyrgyzstan, Tuva, Tajikistan, Mongolia and the Altai. Currently the potanini group is considered to contain 36 species distributed from Hungary to Northeastern Siberia.

COMMENTS. Whereas males of the species in the potanini-group are clearly distinguishable on the basis of unique, species-specific morphology of the palp, females of many species can be very difficult to differentiate because they have very similar epigynes as well as strong intraspecific variation in epigynal morphology.
Parasyrisca kosachevi sp.n.

Figs 2, 5-6, 11-12, 17-18, 22, 27-28, Map 1.

TYPES. MONGOLIA: Bayan-Ölgii Aimag: holotype $O^{7}$ (ISEA) and paratypes 9 우 (ISEA) 9 우 (ZMMU) Cengel-KhairkhanNuruu Mt. Range, $3 \mathrm{~km} \mathrm{~W}$ from Yolt-Uul Mt. $\left(48^{\circ} 09^{\prime} \mathrm{N}, 89^{\circ} 14^{\prime} \mathrm{E}\right)$, scree under rock, $2700 \mathrm{~m}, 11.07 .2015$ (A.A. Fomichev).

ETYMOLOGY. The specific name is a patronym in honour of botanist Petr A. Kosachev (Barnaul, Russia) who helped to organize an expedition to Mongolia in which specimens of new Parasyrisca species were collected.

DIAGNOSIS. The new species is related to three Siberian species: $P$. asiatica Ovtsharenko et al., 1995, P. logunovi Ovtsharenko et al., 1995, and P. bucklei Marusik et Fomichev, 2010 (see Ovtsharenko et al. [1995]: figs 57-61, 62-66; Marusik, Fomichev [2010]: figs 1-15). The male of the new species can be easily distinguished from males of the sibling species by its relatively broad nail-shaped embolus (narrow and sharply pointed in the sibling species). The female of the new species differs from the females of the sibling species by its relatively wide anterior hood about $3 / 4$ of the width of the posterior hood (2-3 times narrower than the posterior hood in the sibling species).

DESCRIPTION. Male (holotype). Total length 8.5. Carapace 3.8 long, 3.1 wide. Coloration. Carapace lightbrown. Chelicerae dark-brown. Sternum, labium and endites brown. Legs and palps yellow-brown. Abdomen and spinnerets yellow-gray. Leg measurements: I $15.3(3.95+2.1+4.1+3.2+1.95) ;$ II $12.6(3.45+$ $1.85+3.2+2.45+1.65)$; III $11.1(3.2+1.6+2.65+$ $2.15+1.5)$; IV $14.4(4.0+1.75+3.8+3.1+1.75)$. Leg spination: I Fe d1-1-0, p0-0-1 Ti v2-2-0 Mt v2-00, II Fe d1-1-0 p0-0-1 Ti v1-2-0 Mt v2-0-0, III Fe d11-0 p0-1-1 r0-1-1 Ti p1-1-1 r1-0-1 v2-2-2 Mt d0-1-0-2 p0-1-0-1 r0-1-0-1 v2-0-0-2, IV Fe d1-1-0 r0-0-1 Ti p10-3 r1-0-1 v1-2-2 Mt d1-1-0-2 p0-1-0-1 r0-2-0-1 v2-0$0-3$.

Palp as in Figs 2, 5-6, 11-12, 17-18, 22. Tibia relatively short, about 2 times longer than wide; retrolateral tibial apophysis as long as tibia width; apophysis with several small tubercles basally. Cymbium 1.7 times longer than wide. Tegulum almost 2 times longer than wide (ratio 11/6). Conductor straight and broad, tip truncate, tip wider than base. Terminal apophysis broad, gradually bent, not hidden by membranous part of tegulum. Embolus wide, nail-shaped.

Female. Total length 9.7. Carapace 4.5 long, 3.5 wide. Coloration. Carapace brown. Chelicerae, labium, endites and sternum dark-brown. Legs, palps, abdomen and spinnerets as in male. Leg measurements: I 12.65 $(3.5+2.0+3.05+2.3+1.8) ;$ II $11.55(3.25+1.8+$ $2.7+2.05+1.75)$; III $10.55(3.05+1.6+2.35+1.9+$ 1.65); IV $14.15(4.0+1.85+3.45+2.95+1.9)$. Leg spination: I Fe d1-1-0, p0-0-1 Ti v1-2-0 Mt v2-0-0, II Fe d1-1-0 p0-0-1 Ti v1-1-0 Mt v2-0-0, III Fe d1-1-0 p0-1-1 r0-0-1 Ti p0-1-1 r0-1-1 v1-1-2 Mt d1-0-0-2 p01-0-1 r0-1-0-1 v2-0-0-2, IV Fe d1-1-0 r0-0-1 Ti p1-0-1 r1-0-1 v1-2-2 Mt d2-0-0-2 p0-1-0-1 r0-1-0-1 v0-2-0-2. 


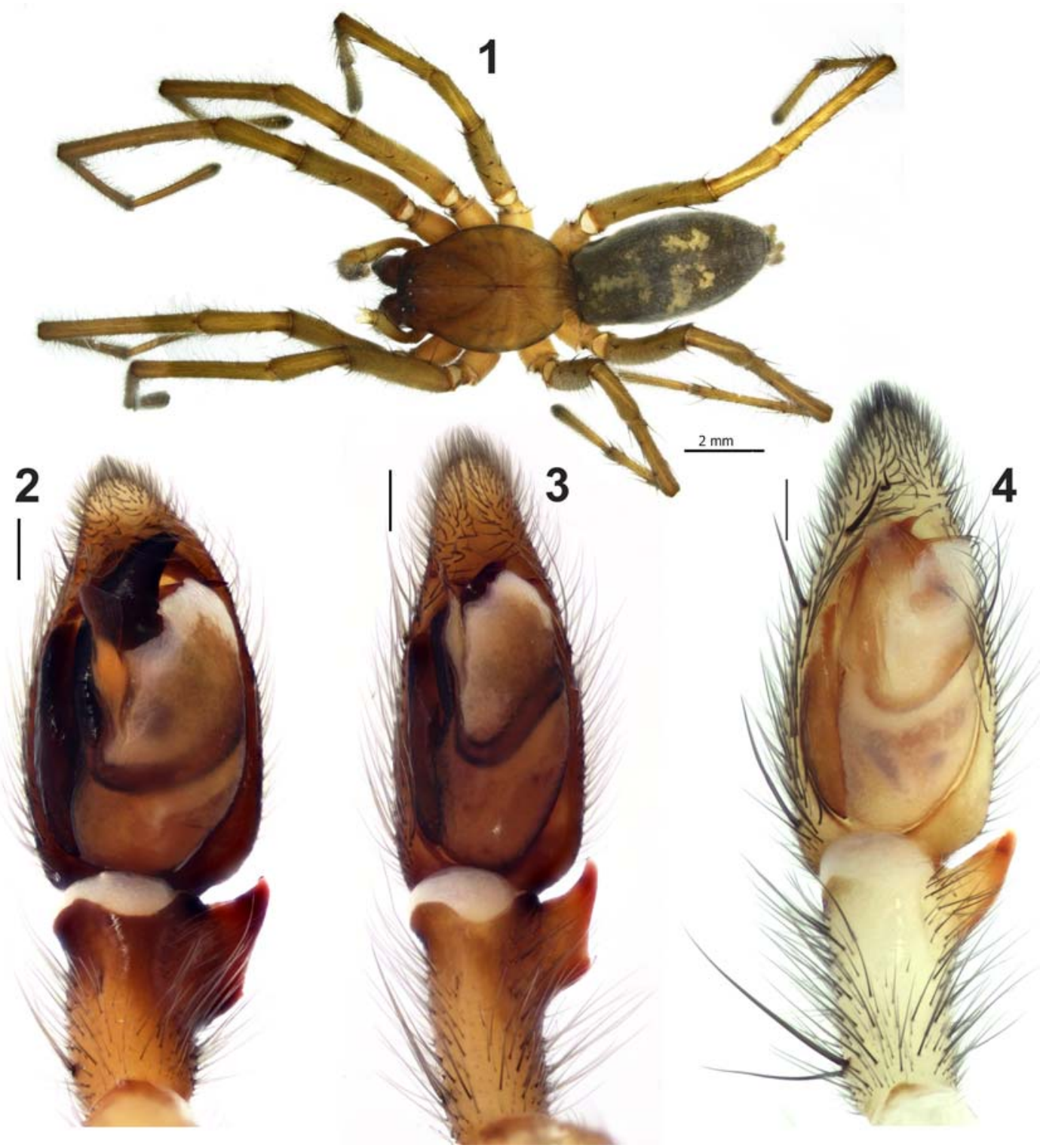

Figs 1-4. Habitus and ventral view of left male palp of Parasyrisca tronovorum sp.n. (1, 3), P. kosachevi sp.n. (2), and P. sulaki sp.n. (4). 1 - male habitus, dorsal; $2-4-$ palp. Scale $=0.2 \mathrm{~mm}$ if not otherwise indicated.

Рис. 1-4. Внешний вид и вентральный вид левой пальпы Parasyrisca tronovorum sp.n. (1, 3), P. kosachevi sp.n. (2) и P. sulaki sp.n. (4). 1 - внешний вид самца, дорсально; 2-4 - пальпа. Масштаб 0,2 мм, если не указано иначе.

Epigyne as in Figs 27-28; as long as wide. Fovea as long as wide, lateral margins almost parallel. Anterior hood wide, about $3 / 4$ of the width of the posterior hood. Copulatory openings located in anterior $1 / 3$ of fovea, openings separated by a distance equal to entire width of posterior hood. Posterior hood anchor-shaped. Receptacles straight, nearly parallel. Head of receptacles separated by 2 diameters, terminating level with anterior hood.

Size variation. Females vary from 9.2 to 10.6 in the body length, carapace 4.0-4.9 long and 3.1-3.9 wide $(n=4)$.
DISTRIBUTION. Known from the type locality only.

\section{Parasyrisca tronovorum sp.n.}

Figs 1, 3, 7-8, 13-14, 20-21, 23-24, 29-30, Map 1.

TYPES. MONGOLIA: Khovd Aimag: holotype $0^{7}$ (ISEA) and paratypes 4 우 (ISEA), Dzhargalant-Khairkhan Mt. Range, watershed of Ar-Shaatyn-Gol River and Dund-Uliastain-Gol River $\left(47^{\circ} 42^{\prime} \mathrm{N}, 92^{\circ} 30^{\prime} \mathrm{E}\right)$, scree, $3300-3700 \mathrm{~m}, 25.06 .2015$ (A.A. Fomichev).

ETYMOLOGY. The species is dedicated to brothers Boris V. and Mikhail V. Tronov, famous mountaineers who initiated a systematic study of the highlands of the Altai Mountains. 

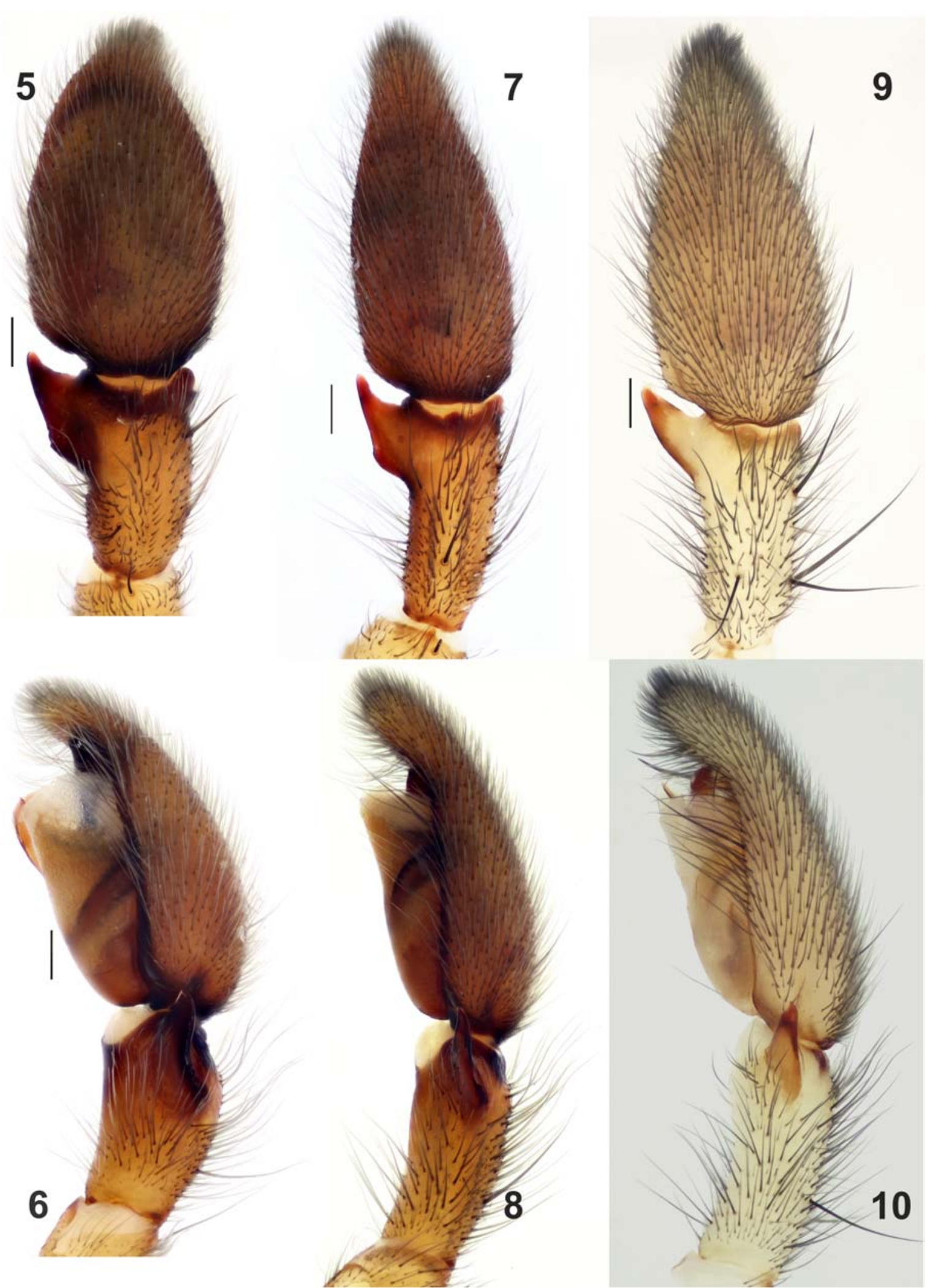

Figs 5-10. Left male palp of Parasyrisca kosachevi sp.n. (5-6), P. tronovorum sp.n. (7-8), and P. sulaki sp.n. (9-10). 5, 7, $9-$ dorsal; 6, 8, 10- retrolateral. Scale $=0.2 \mathrm{~mm}$.

Рис. 5-10. Левая пальпа самца Parasyrisca kosachevi sp.n. (5-6), P. tronovorum sp.n. (7-8) и P. sulaki sp.n. (9-10). 5, 7, $9-$ дорсально; 6, 8, 10 - ретролатерально. Масштаб 0,2 мм. 

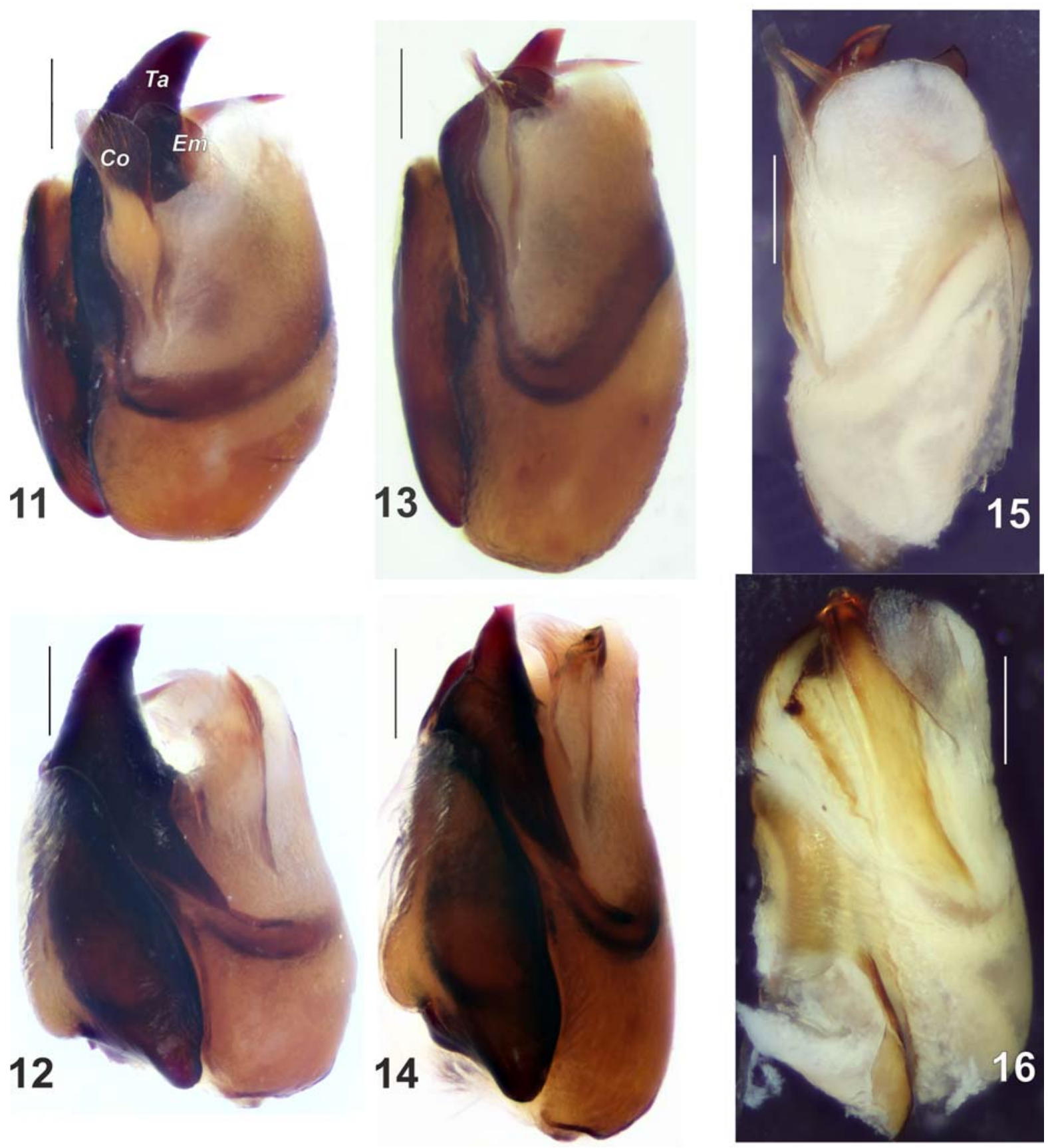

Figs 11-16. Left bulb of Parasyrisca kosachevi sp.n. (11-12), P. tronovorum sp.n. (13-14) and P. sulaki sp.n. (15-16). 11, 13, 15 ventral; $12,14,16$ - prolateral. Scale $=0.2 \mathrm{~mm}$.

Рис. 11-16. Левый бульбус Parasyrisca kosachevi sp.n. (11-12), P. tronovorum sp.n. (13-14) и P. sulaki sp.n. (15-16). 11, 13, 15 вентрально; 12, 14, 16 - пролатерально. Масштаб 0,2 мм.

DIAGNOSIS. This species is most similar to $P$. tyshchenkoi Ovtsharenko et al., 1995 (Figs 35, 38, 43). The male of $P$. tronovorum sp.n. can be separated from the male of the sibling species by its widened embolus with prolaterally curved tip (straight in P. tyshchenkoi) as well as by its relatively longer tibia, narrower cymbium, and broader conductor. The female of the new species can be distinguished from the female of $P$. tyshchenkoi by its relatively thin posterior epigynal hood (about 2 times thicker in $P$. tyshchenkoi). The female of P. tronovorum sp.n. is also similar to the females of some other species of the potanini-group: $P$. asiatica, $P$. sulaki sp.n. and $P$. helanshan Tang et Zhao, 1998. From $P$. asiatica and $P$. sulaki sp.n. the female of $P$. tronovorum sp.n. can be distinguished by its outwardly stretched atrial epigynal pockets. From 


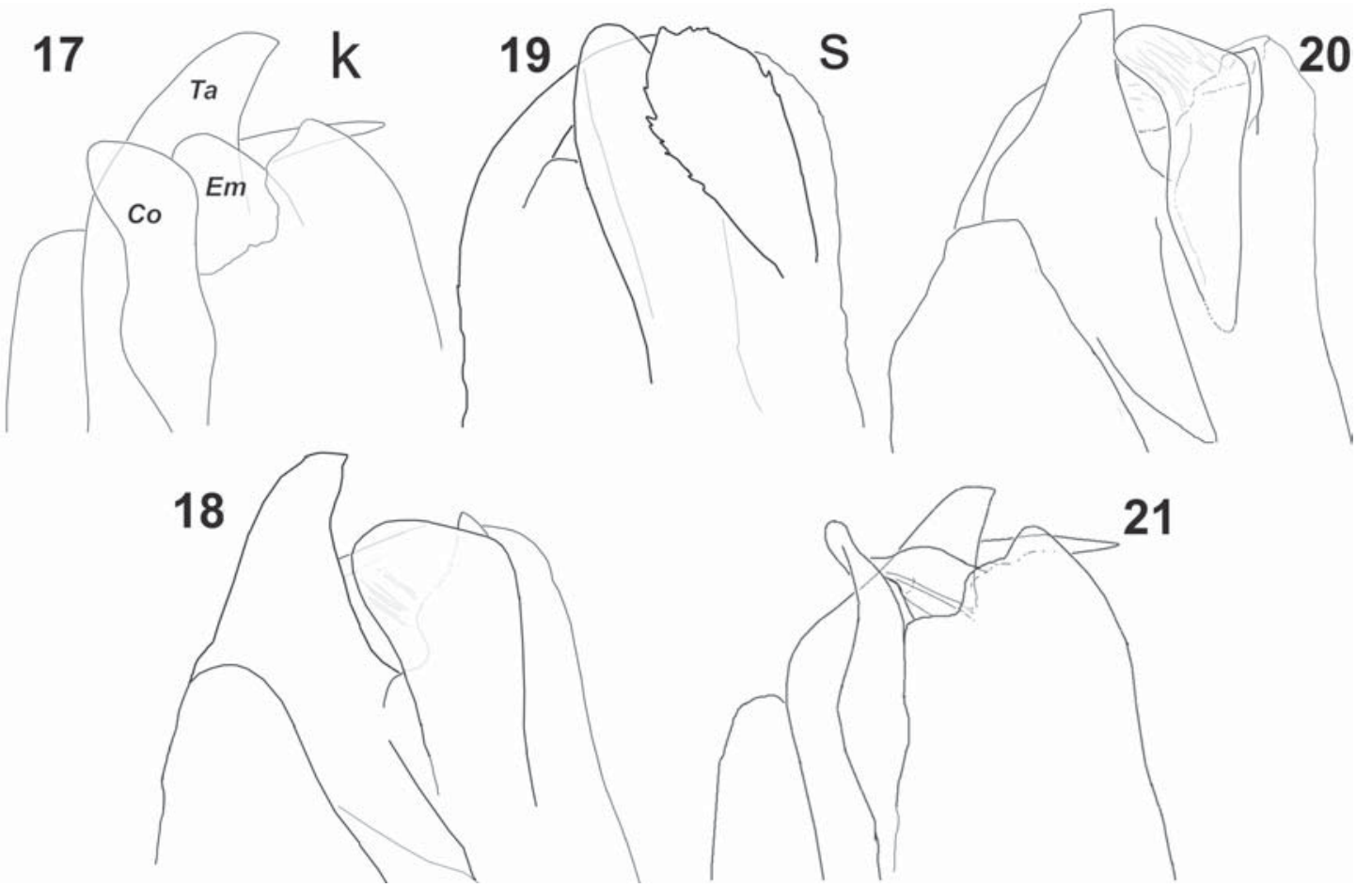

Figs 17-21. Terminal part of left bulb of Parasyrisca kosachevi sp.n. (17-18), P. sulaki sp.n. (19) and P. tronovorum sp.n. (20-21). 17,21 - ventral; $18-20$ - prolateral.

Рис. 17-21. Верхняя часть левого бульбуса Parasyrisca kosachevi sp.n. (17-18), P. sulaki sp.n. (19) и P. tronovorum sp.n. (2021). 17, 21 - вентрально; 18-20 - пролатерально.

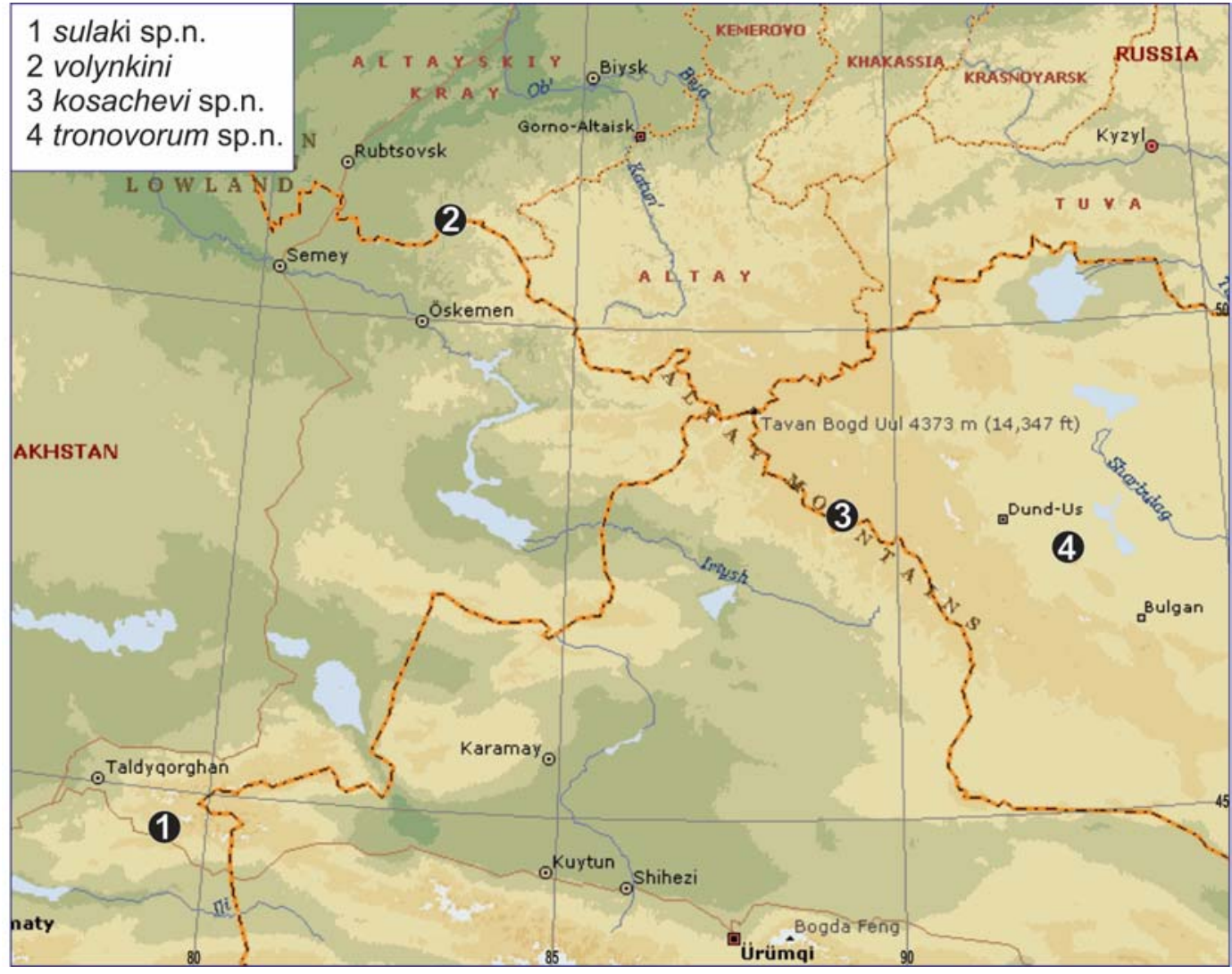

Map 1. Type localities of Parasyrisca sulaki sp.n. (1), P. volynkini (2), P. kosachevi sp.n. (3) and P. tronovorum sp.n. (4).

Карта 1. Типовые местообитания Parasyrisca sulaki sp.n. (1), P. volynkini (2), P. kosachevi sp.n. (3) и P. tronovorum sp.n. (4). 

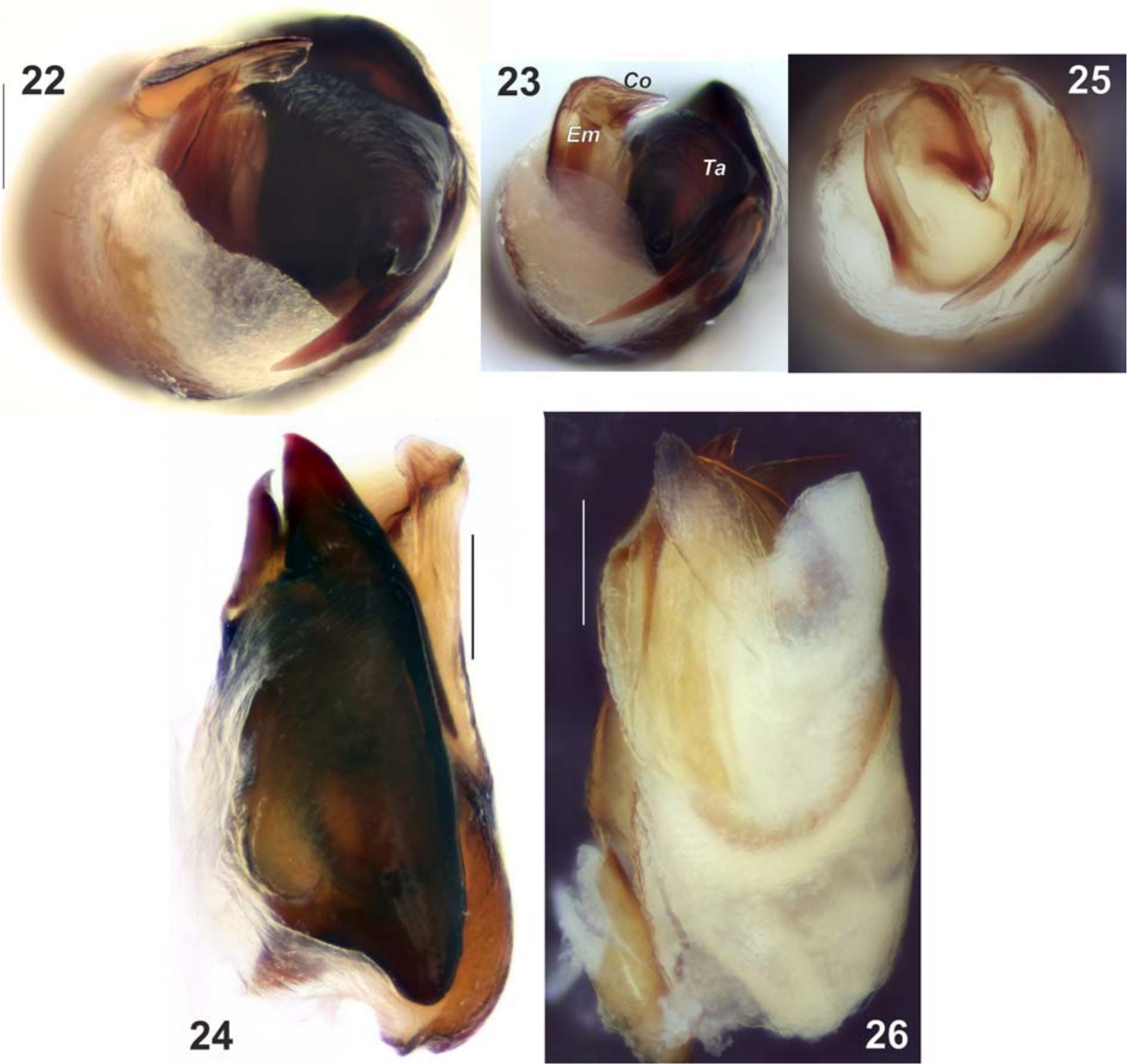

Figs 22-26. Left bulb of Parasyrisca kosachevi sp. n. (22), P. tronovorum sp.n. (23-24) and P. sulaki sp.n. (25-26). 22-23, $25-$ apical; 24 - dorso-prolateral; 26 - ventral. Scale $=0.2 \mathrm{~mm}$.

Рис. 22-26. Левый бульбус Parasyrisca kosachevi sp. n. (22), P. tronovorum sp.n. (23-24) и P. sulaki sp.n. (25-26). 22-23, $25-$ апикально; 24 - спереди; 26 - вентрально. Масштаб 0,2 мм.

$P$. helanshan the female of the new species can be differentiated by its relatively thin posterior epigynal hood and wide anterior epigynal hood (about twice as thick and half as wide, respectively, in the female of $P$. helanshan).

DESCRIPTION. Male (holotype). Total length 9.7. Carapace 4.2 long, 3.3 wide. Coloration. Carapace brown. Chelicerae, labium, endites, and sternum darkbrown. Legs and palps yellow-brown. Abdomen gray dorsally, yellow-gray ventrally. Spinnerets yellow-gray. Leg measurements: I $17.55(4.5+2.45+4.6+3.7+$ 2.3); II $14.3(3.95+2.15+3.55+2.75+1.9)$; III 12.6 $(3.55+1.8+3.0+2.5+1.75) ;$ IV $16.85(4.6+2.05+$ $4.35+3.8+2.05)$. Leg spination: I Fe d1-1-0 p0-0-1
Ti v2-2-0 Mt v2-0-0 II Fe d1-1-0 p0-1-1 Ti v1-2-0 Mt v2-0-0, III Fe d1-1-0 p0-1-1 r0-1-1 Ti p2-0-1 r1-0-1 v2-2-2 Mt d2-0-0-2 p0-1-0-1 r1-0-0-1 v2-0-0-2, IV Fe d1-1-0 p0-0-1 r0-0-1 Ti p1-1-1 r2-1-1 v2-2-2 Mt d2-00-2 p0-1-0-1 r1-1-0-1 v1-1-0-2.

Palp as in Figs 3, 7-8, 13-14, 20-21, 23-24. Tibia elongate, 2.5 time longer than wide; tibial apophysis about half as long as tibia; tibial apophysis straight and flat in lateral view, with 1 basal tooth. Cymbium 2.35 times longer than wide. Conductor with bent tip, width of tip subequal to width of conductor base. Embolus widened, tip prolaterally curved. Terminal apophysis bent at angle of about 120 degrees. 

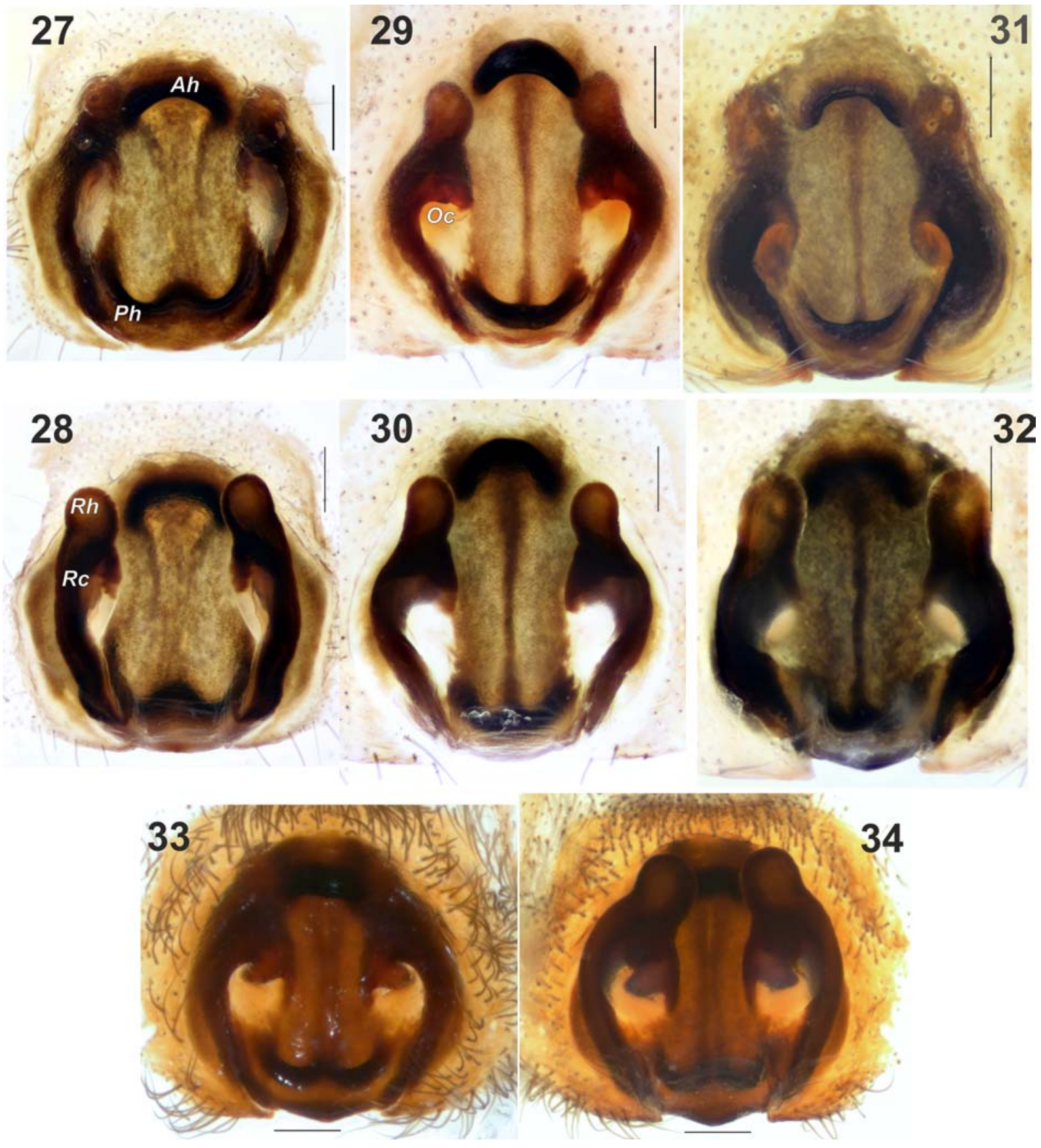

Figs 27-34. Epigyne of Parasyrisca kosachevi sp.n. (27-28), P. tronovorum sp.n. (29-30), P. sulaki sp.n. (31-32) and P. volynkini (33-34). 27, 29, 31, 33 - ventral; 28, 30, 32, 34 - dorsal. Scale $=0.2 \mathrm{~mm}$.

Рис. 27-34. Эпигина Parasyrisca kosachevi sp.n. (27-28), P. tronovorum sp.n. (29-30), P. sulaki sp.n. (31-32) и P. volynkini (3334). 27, 29, 31, 33 - вентрально; 28, 30, 32, 34 - дорсально. Масштаб 0,2 мм.

Female. Total length 10.7. Carapace 4.7 long, 3.6 wide. Coloration as in male, but abdomen fully yellowgray. Leg measurements: I $14.6(4.05+2.3+3.6+2.7+$ $1.95) ;$ II $13.5(3.85+2.15+3.2+2.5+1.8) ;$ III 12.4 $(3.6+1.85+2.9+2.35+1.7) ;$ IV $16.65(4.6+2.15+$ $4.25+3.7+1.95)$. Leg spination: I Fe d1-1-0 p0-0-1 Ti v2-2-0 Mt v2-0-0, II Fe d1-1-0 p0-1-1 Ti v1-2-0 Mt v2-0-0, III Fe d1-1-0 p0-1-1 r0-1-1 Ti p1-1-1 r1-0-1 v2-2-2 Mt d2-0-0-2 p0-1-0-1 r0-1-0-1 v2-0-0-2, IV Fe d1-1-0 p0-0-1 r0-1-1 Ti p1-1-1 r2-1-1 v2-2-2 Mt d2-00-2 p0-1-0-1 r0-1-0-1 v1-1-0-2.

Epigyne as in Figs 29-30, plate and fovea about 1.1 times longer than wide. Anterior hood almost as wide as posterior hood. Posterior hood horseshoe-shaped. Copulatory openings located about half way between anterior and posterior hoods, distance between open- 

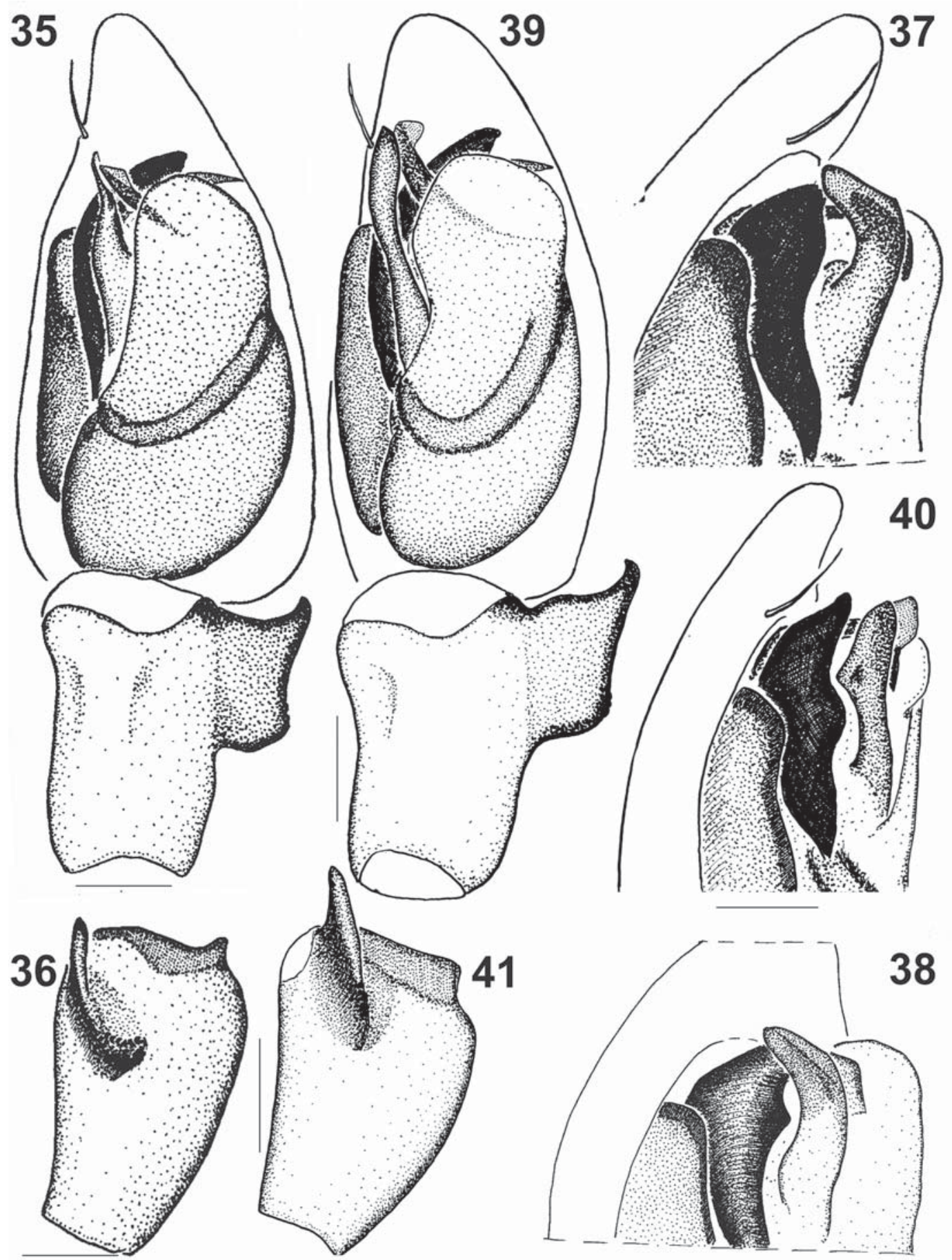

Figs 35-41. Male palp of Parasyrisca tyshchenkoi (35-38) and P. holmi (39-41). 35, 39 - ventral; 36, 41 — tibia, retrolateral; 37, 40 terminal part of palp, prolateral; 38 - terminal part of palp, ventro-prolateral. Scale $=0.2 \mathrm{~mm}$.

Рис. 35-41. Пальпа самца Parasyrisca tyshchenkoi (35-38) и P. holmi (39-41). 35, 39 - вентрально; 36, 41 - голень, ретролатерально; 37, 40 - вершинная часть пальпы, пролатерально; 38 - вершинная часть пальпы, вентро-пролатерально. Масштаб 0,2 мм.

ings 1.5 longer than entire width of posterior hood. Atrial epigynal pockets stretched outwardly. Receptacles not parallel, ectally rounded medially. Heads of receptacles separated by 2.5 diameters, terminating just posterior to anterior hood.
Size variation. Females vary from 8.6 to 10.7 in the body length, carapace 4.2-5.2 long, 3.3-4.1 wide $(n=4)$.

DISTRIBUTION. Known from the type locality only. 

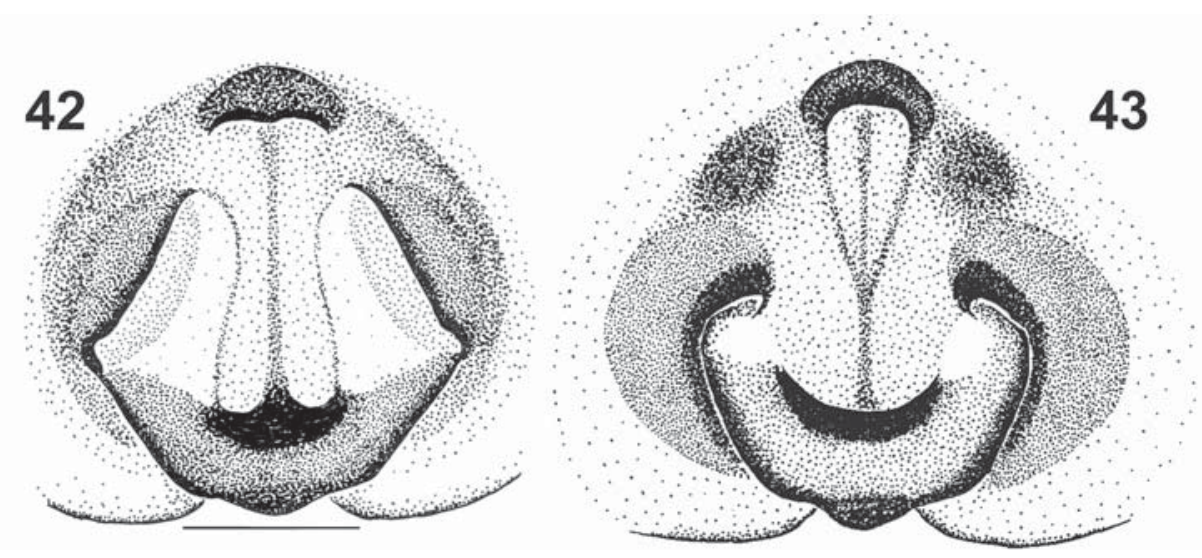

Figs 42-43. Ventral view of epigyne of Parasyrisca holmi (42) and P. tyshchenkoi (43). Scale $=0.2 \mathrm{~mm}$. Рис. 42-43. Эпигина Parasyrisca holmi (42) и P. tyshchenkoi (43). Масштаб 0,2 мм.

COMMENTS. Collected at elevations from 3300 to $3700 \mathrm{~m}, P$. tronovorum sp.n. appears to occur at the highest elevation of all temperate zone species of Parasyrisca. Other species of Parasyrisca have been found at higher elevations only in the subtropics, $7^{\circ}$ to $13^{\circ}$ south of the type locality of $P$. tronovorum sp.n., in the Alay, Pamir, and Karakoram Mountains. The new species is likely to be an endemic species of the orographically isolated Dzhargalant-Khairkhan Mt. Range.

Parasyrisca sulaki sp.n.

Figs 4, 9-10, 15-16, 19, 25-26, 31-32, Map 1.

TYPES. KAZAKHSTAN: Almaty Region: holotype $0^{7}$ (ISEA) and paratype 1 (ISEA) watershed of the Ermenesai and Koksai Rivers $\left(44^{\circ} 43^{\prime} \mathrm{N}, 79^{\circ} 19^{\prime} \mathrm{E}\right)$, stony alpine meadow with screes, 2900 3000 m, 3.07.2016 (A.A. Fomichev).

ETYMOLOGY. The specific name is a patronym in honour of entomologist Harold Sulak (Munich, Germany) who helped to organize the expedition to Kazakhstan during which this new species was collected.

DIAGNOSIS. The male of the new species is similar to that of $P$. holmi Ovtsharenko et al., 1995, but differs from it by the longer tibia, narrower cymbium, and the shape of the tibial apophysis (cf. Figs 4, 9-10 and 39,41 ) as well as by much broader conductor and tapering, prolaterally curved embolus (conductor long and thin and embolus wide and medially curved embolus in $P$. holmi). The epigyne of $P$. sulaki sp.n. is similar to the epigynes of several other species such as $P$. asiatica, $P$. bucklei, $P$. logunovi, $P$. tronovorum sp.n., and $P$. tyschenkoi. The female of $P$. sulaki sp.n. can be separated from those of $P$. asiatica and $P$. bucklei by the head of receptacles terminating level with the anterior hood, from those of $P$. logunovi and $P$. tyschenkoi by narrower posterior hood, and from $P$. tronovorum sp. n. by the epigynal pockets not being stretched outward.

DESCRIPTION. Male (holotype). Total length 9.2. Carapace 4.1 long, 3.2 wide. Coloration (recently molted specimen). Prosoma, all limbs and spinnerets daffodil. Sternum and labium slightly darker. Abdomen yellow- gray. Leg measurements: I $17.25(4.45+2.2+4.6+$ $3.75+2.25) ;$ II $13.95(3.8+1.9+3.6+2.8+1.85)$; III $12.3(3.55+1.7+3.1+2.35+1.6) ;$ IV $16.2(4.45+$ $1.95+4.35+3.6+1.85)$. Leg spination: I Fe d1-1-0 p0-0-1 Ti v1-2-0 Mt v2-0-0, II Fe d1-1-0 p0-1-1 Ti v02-1 Mt v2-0-0, III Fe d1-1-0 p0-1-1 r0-1-1 Ti p1-0-1 r1-0-1 v1-2-2 Mt d2-0-0-2 p1-0-0-1 r1-0-0-1 v2-0-0-2, IV Fe d1-1-0 p0-0-1 r0-0-1 Ti p1-0-1 r1-1-1 v2-2-2 Mt d2-0-0-2 p0-1-0-1 r1-0-0-1 v1-1-0-2.

Palp as in Figs 4, 9-10, 15-16, 19, 25-26. Tibia 2.5 times longer than wide, length of tibial apophysis equal to width of tibia, apophysis gradually tapering in ventral and dorsal views. Cymbium 2.19 times longer than wide. Conductor petal-like, broad near tip, narrower near base. Embolus narrow, sharply pointed.

Female. Total length 13.0. Carapace 5.0 long, 3.9 wide. Coloration. Carapace brown, darker in the cephalic part. Chelicerae, labium, endites and sternum darkbrown. Legs and palps yellow-brown, darker distally. Abdomen dirty cream-colored. Spinnerets yellowbrown. Leg measurements: I $15.5(4.25+2.3+3.95+$ $3.0+2.0)$, II $14.35(4.05+2.15+3.6+2.7+1.85)$, III $13.35(3.9+2.0+3.25+2.5+1.7)$, IV $17.3(4.85+$ $2.25+4.5+3.7+2.0)$. Leg spination: I Fe d1-1-0 p00-1 Ti v0-2-0 Mt v2-0-0, II Fe d1-1-0 p0-1-1 Ti v0-2-1 Mt v2-0-0, III Fe d1-1-0 p0-1-1 r0-1-1 Ti p2-0-1 r1-01 v1-2-2 Mt d0-2-0-2 p0-1-0-1 r0-1-0-1 v2-0-0-2, IV Fe d1-1-0 p0-0-1 r0-0-1 Ti p1-2-1 r1-1-1 v2-2-2 Mt d2-0-0-2 p0-1-0-1 r0-1-0-1 v2-0-0-2.

Epigyne as in Figs 31-32; epigynal plate longer than wide; fovea almost 2 times longer than wide. Anterior hood almost as wide as posterior hood. Posterior hood thickened, horseshoe-shaped. Copulatory openings located in posterior half of fovea. Receptacles almost parallel, slightly curved outwards posteriorly. Heads of receptacles nearly 2 diameters apart and terminating level with anterior hood.

DISTRIBUTION. Known from the type locality only.

COMMENTS. The holotype male is a recently molted and weakly chitinized. 
Parasyrisca volynkini Fomichev, 2016 Figs 33-34, Map 1. $\left(O^{7}\right)$.

Parasyrisca volynkini Fomichev, 2016: 120, figs 5-9, 13-14

MATERIAL EXAMINED. RUSSIA: Altai Province: holotype $\sigma^{7}$ (ISEA, 001.6269) Tigirek Mt. Range, Razrabotnaya Mt. (51 ${ }^{\circ}$ $01^{\prime} \mathrm{N}, 83^{\circ} 01^{\prime} \mathrm{E}$ ), kurum (scree formed by huge boulders), 1800 $1960 \mathrm{~m}, 31.07 .2014$ (A.A. Fomichev); 2 우 (ISEA) same place $\left(51^{\circ} 02^{\prime} \mathrm{N}, 83^{\circ} 01^{\prime} \mathrm{E}\right)$, kurum, $1700-1960 \mathrm{~m}, 13.07 .2016$ (V.V. Sidorov).

DIAGNOSIS. The male of $P$. volynkini is similar to those of three south-Siberian species: $P$. altaica Ovtsharenko et al., 1995, P. bucklei and P. logunovi, but can be separated from the latter two by the curved distal part of its conductor (straight in the sibling species) and from $P$. altaica by the parallel margins of the conductor when viewed prolaterally (conductor with an extended terminal part in the male of $P$. altaica). The females of $P$. volynkini and $P$. altaica can be separated by the thinner posterior hood and more closely spaced heads of the receptacles in the former. From $P$. bucklei and P. asiatica it differs by the heads of the receptacles being separated by about one diameter (separated by 2 and 3 diameters in $P$. bucklei and $P$. asiati$c a$, respectively). The females of $P$. volynkini and $P$. belukha Ovtsharenko et al., 1995 are also similar but can be distinguished by the thicker lateral parts of the posterior hood and the heads of receptacles terminating anteriorly to the anterior hood in $P$. volynkini. From $P$. logunovi the female of $P$. volynkini is separated by the ectal curving of the medial part of its receptacles.

DESCRIPTION. Female. Total length 11.1. Carapace 4.5 long, 3.8 wide. Coloration: carapace brown; chelicerae, labium, endites, and sternum dark-brown; legs and palps yellow-brown, darker distally; abdomen and spinnerets yellow-gray. Leg measurements: I 13.6 $(3.9+1.95+3.55+2.55+1.65) ;$ II $12.5(3.7+1.8+$ $3.05+2.4+1.55) ;$ III $11.7(3.45+1.75+2.9+2.15+$ 1.45); IV $14.45(4.15+1.9+3.55+3.15+1.7)$. Leg spination: I Fe d1-1-0 p0-0-1 Ti v2-2-0 Mt v2-0-0, II Fe d1-1-0 p0-1-1 Ti 2-2-0 Mt v2-0-0, III Fe d1-1-0 p0-1-1 r0-1-1 Ti p2-0-1 r1-0-1 v2-2-2 Mt d0-2-0-2 p0-1-0-1 r0-1-0-1 v1-1-0-2, IV Fe d1-1-0 r0-0-1 Ti p1-0-1 r1-1-1 v1-2-2 Mt d2-0-0-2 p0-1-0-1 r0-1-0-1 v0-2-0-2.

Epigyne as in Figs 33-34; plate as long as wide; fovea wider than long. Anterior hood about half as wide as posterior hood. Posterior hood horseshoeshaped. Copulatory openings located in anterior $1 / 3$ of fovea. Medial part of receptacles curved outwards. Heads of receptacles separated by about one diameter and terminating slightly anterior of the anterior hood.

Size variation. Total length 11.1-11.3; carapace 4.05-4.5 long and 3.5-3.8 wide $(\mathrm{n}=2)$.

DISTRIBUTION. Known from the type locality only.

\section{Species grouping}

In his revision of Parasyrisca Ovtsharenko et al. [1995] recognized 44 species in four species groups: potanini, vinosa, guzeripli and breviceps. Subsequently the number of named species has risen to 54 and the accumulation of new data on morphology and distribution allow us to reconsider species groupings within the genus.

The vinosa-group. Recently, the vinosa-group was revised and rediagnosed [Marusik, Fomichev, 2016] with four species recognized in the group: P. golyakovi, P. marusiki, P. vinosa (Simon, 1878), and P. ulykpani Ovtsharenko et al., 1995. Although a small group, it has a wide and disjunct range from the Pyrenees $\left(2^{\circ} \mathrm{E}\right)$ to Central Mongolia $\left(115^{\circ} \mathrm{E}\right)($ Map 2$)$.

The breviceps-group. This group, diagnosed only in Ovtsharenko et al. (1995), includes 10 species: $P$. andreevae Ovtsharenko et al., 1995, P. anzobica Ovtsharenko et al., 1995, P. breviceps (Kroneberg, 1875), P. chikatunovi Ovtsharenko et al., 1995, $P$. gissarika Ovtsharenko et al., 1995, P. iskander Ovtsharenko et al., 1995, P. koksu Ovtsharenko et al., 1995, P. paironica Ovtsharenko et al., 1995, P. shakhristanica Ovtsharenko et al., 1995, and P. vorobica Ovtsharenko et al., 1995. Although it is the second largest species group, its distribution is restricted to a small area of the Ghissar-Alai and Pamir Mountains and, unlike the other species groups, has no disjunction in its distribution (Map 2).

The guseripli-group. This group, originally suggested for a single species, $P$. guzeripli Ovtsharenko et al., 1995, now may contain (with some reservations) three more species: P. turkenica Ovtsharenko et al., 1995, P. arrabonica Szinetár et Eichardt, 2009, and $P$. songi Marusik et Fritzén, 2009. The two former species were considered previously in the potanini-group. All three share a conical tibial apophysis, a much longer than wide epigyne, a very small fovea (atrium), and short receptacles not reaching the anterior hood. Alternatively, the position of the embolus in these species suggest that they may belong to a new turkenica-group. Here we take the conservative approach and place them provisionally in the guseripli-group. This group has a wide but strongly disjunct range in the West Palaearctic from Hungary $\left(20^{\circ} \mathrm{E}\right)$ to Xinjiang $\left(90^{\circ} \mathrm{E}\right)$ (Map 2).

The potanini-group. This, the largest of the Parasyrisca species groups, contains 36 species (Table 1): P. alai Ovtsharenko et al., 1995, P. alexeevi Ovtsharenko et al., 1995, P. altaica, P. andarbag Ovtsharenko et al., 1995, P. asiatica, P. balcarica Ovtsharenko et al., 1995, P. belengish Ovtsharenko et al., 1995, P. belukha, P. birikchul Ovtsharenko et al., 1995, P. bucklei, P. caucasica Ovtsharenko et al., 1995, P. heimeri Ovtsharenko et al., 1995, P. helanshan, P. hippai Ovtsharenko et al., 1995, P. holmi, P. khubsugul Ovtsharenko et al., 1995, P. kosachevi sp.n., P. kurgan Ovtsharenko et al., 1995, P. kyzylart Ovtsharenko et al., 1995, P. logunovi, P. mikhailovi Ovtsharenko et 


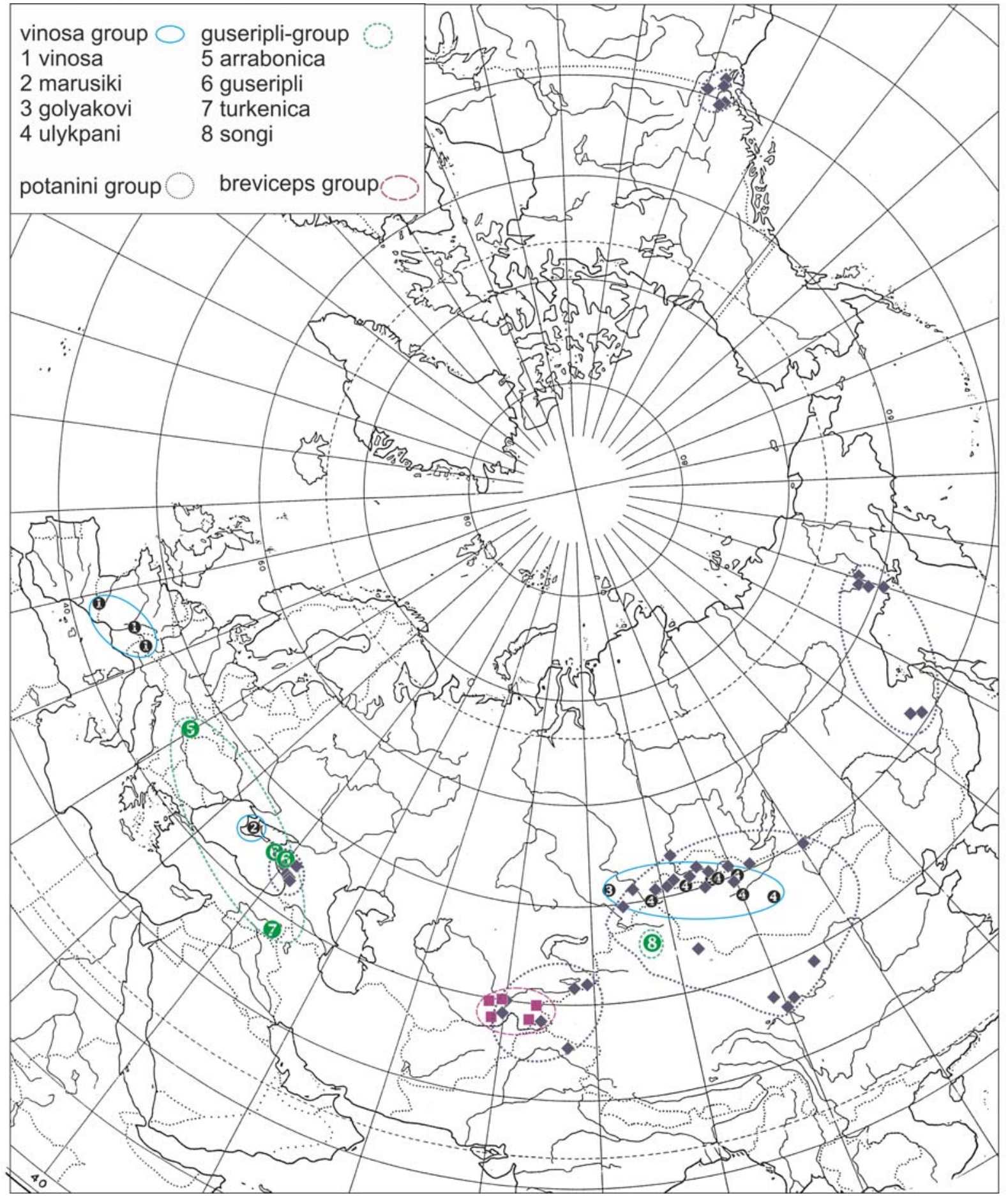

Map 2. Distribution records of the four species groups of Parasyrisca.

Карта 2. Распространение четырёх групп видов Parasyrisca.

al., 1995, P. narynica Ovtsharenko et al., 1995, P. orites (Chamberlin et Gertsch, 1940), P. otmek Ovtsharenko et al., 1995, P. pamirica Ovtsharenko et al., 1995, P. potanini Schenkel, 1963, P. pshartica Ovtsharenko et al., 1995, P. schenkeli Ovtsharenko et Marusik, 1988, P. sollers (Simon, 1895), P. sulaki sp.n., P. susamyr Ovtsharenko et al., 1995, P. terskei Ovtsharenko et al., 1995, P. tronovorum sp.n., P. tyshchenkoi, P. vakhanski Ovtsharenko et al., 1995 and $P$. volynkini. It was well diagnosed by Ovtsharenko et al. (1995). Its range is of a similar size to the range of the vinosa-group: from Western Caucasus $\left(40^{\circ} \mathrm{E}\right)$ to north- 
Table 1. List of species belonging to the Parasyrisca potanini-group and their distribution. Таблица 1. Таксономический состав Parasyrisca potanini-group и распространение включаемых видов.

\begin{tabular}{|c|c|c|c|}
\hline Species & $\begin{array}{l}\text { Known } \\
\text { sexes }\end{array}$ & Distribution and elevation (if known) & Latitude and longitude \\
\hline P. alai & $\sigma^{2}$ & $\begin{array}{l}\text { Alay Mountains (3615 m), Karakoram (3900-4200 } \\
\text { m) }\end{array}$ & $35-40^{\circ} \mathrm{N}, 73-75^{\circ} \mathrm{E}$ \\
\hline P. alexeevi & q & W Caucasus & $43^{\circ} \mathrm{N}, 44^{\circ} \mathrm{E}$ \\
\hline P. altaica & $\sigma^{2} \phi$ & Altai Mountains (1327 m) & $45-48^{\circ} \mathrm{N}, 84-87^{\circ} \mathrm{E}$ \\
\hline P. andarbag & q & Pamir (2000 m) & $38^{\circ} \mathrm{N}, 72^{\circ} \mathrm{E}$ \\
\hline P. asiatica & $\sigma^{2}+$ & $\begin{array}{l}\text { Altai Mountains (1800-3000 m), Tuva (1500-3300 } \\
\text { m) }\end{array}$ & $49-50^{\circ} \mathrm{N}, 88-91^{\circ} \mathrm{E}$ \\
\hline P. balcarica & $\sigma^{2}+$ & W Caucasus $(2500-3500 \mathrm{~m})$ & $43-44^{\circ} \mathrm{N}, 42-43^{\circ} \mathrm{E}$ \\
\hline P. belengish & $q$ & Tuva $(1200-1900 \mathrm{~m})$ & $50-51^{\circ} \mathrm{N}, 94-96^{\circ} \mathrm{E}$ \\
\hline P. belukha & q & Altai Mountains & $50^{\circ} \mathrm{N}, 87^{\circ} \mathrm{E}$ \\
\hline P. birikchul & $\sigma^{\top}+$ & Kusnetsk Alatau Mountains & $53^{\circ} \mathrm{N}, 90^{\circ} \mathrm{E}$ \\
\hline P. bucklei & $\sigma^{2} 0$ & Altai Mountains $(2180-3300 \mathrm{~m})$ & $50^{\circ} \mathrm{N}, 88-89^{\circ} \mathrm{E}$ \\
\hline P. caucasica & $\sigma^{7}+$ & Caucasus $(2300-3000 \mathrm{~m})$ & $44^{\circ} \mathrm{N}, 40^{\circ} \mathrm{E}$ \\
\hline P. heimeri & q & Altai Mountains & $44^{\circ} \mathrm{N}, 103^{\circ} \mathrm{E}$ \\
\hline P. helanshan & q & Helan Mountains (central Inner Mongolia) & $39^{\circ} \mathrm{N}, 106^{\circ} \mathrm{E}$ \\
\hline P. hippai & $q$ & Altai Mountains $(2000 \mathrm{~m})$, Tuva $(600-2100 \mathrm{~m})$ & $50-52^{\circ} \mathrm{N}, 86-94^{\circ} \mathrm{E}$ \\
\hline P. holmi & $\sigma^{2}+$ & $\begin{array}{l}\text { Upper Kolyma Upland }(600-1300 \mathrm{~m}) \text {, Magadan }(20 \\
\text { m), Badzhal Mt. Range }(1700 \mathrm{~m})\end{array}$ & $50-63^{\circ} \mathrm{N}, 135-151^{\circ} \mathrm{E}$ \\
\hline P. khubsugul & $\sigma^{7}$ & Khangai Mountains (2100-2600 m) & $48-49^{\circ} \mathrm{N}, 99-100^{\circ} \mathrm{E}$ \\
\hline P. kosachevi sp.n. & $\sigma^{2} \theta_{1}$ & Altai Mountains $(2700 \mathrm{~m})$ & $48^{\circ} \mathrm{N}, 89^{\circ} \mathrm{E}$ \\
\hline P. kurgan & q & Tian Shan Mountains & $41^{\circ} \mathrm{N}, 74^{\circ} \mathrm{E}$ \\
\hline P. kyzylart & o & Pamir (4280 m) & $39^{\circ} \mathrm{N}, 73^{\circ} \mathrm{E}$ \\
\hline P. logunovi & $\sigma^{\top}+$ & Tuva $(3100-3300 \mathrm{~m})$ & $50^{\circ} \mathrm{N}, 90^{\circ} \mathrm{E}$ \\
\hline P. mikhailovi & O & W Caucasus (1700-3000 m) & $43^{\circ} \mathrm{N}, 44^{\circ} \mathrm{E}$ \\
\hline P. narynica & $\sigma^{7}+$ & Tian Shan Mountains, Pamir & $38-42^{\circ} \mathrm{N}, 74-78^{\circ} \mathrm{E}$ \\
\hline P. orites & $\sigma^{2}+$ & Coastal and Cascade Mountains (1800-2400 m) & $47-51^{\circ} \mathrm{N}, 120-122^{\circ} \mathrm{W}$ \\
\hline P. otmek & $q$ & Tian Shan Mountains & $42^{\circ} \mathrm{N}, 73^{\circ} \mathrm{E}$ \\
\hline P. pamirica & O & Pamir (4200 m) & $39^{\circ} \mathrm{N}, 72^{\circ} \mathrm{E}$ \\
\hline P. potanini & $\sigma^{2}+$ & $\begin{array}{l}\text { Tuva }(600-1500 \mathrm{~m}), \text { Khangai Mountains }(1000- \\
2150 \mathrm{~m}), \text { Khentii Mountains }(1200-1600 \mathrm{~m}), \text { Inner } \\
\text { Mongolia, Tibet }\end{array}$ & $34-52^{\circ} \mathrm{N}, 93-110^{\circ} \mathrm{E}$ \\
\hline P. pshartica & o & Pamir (4500-4900 m) & $38^{\circ} \mathrm{N}, 74^{\circ} \mathrm{E}$ \\
\hline P. schenkeli & $\sigma^{7}+$ & $\begin{array}{l}\text { Altai Mts }(2500 \mathrm{~m}) \text {, Tuva }(900-1350 \mathrm{~m}) \text {, Great } \\
\text { Lake Depression }(1350 \mathrm{~m}), \text { Khangai Mts }(1620- \\
1650 \mathrm{~m}), \text { Khentii Mts }(1380 \mathrm{~m}) \text {, Gobi Desert } \\
(1480-1700 \mathrm{~m}), \text { Gansu }\end{array}$ & $38-50^{\circ} \mathrm{N}, 83-114^{\circ} \mathrm{E}$ \\
\hline P. sollers & q & Altai Mountains, Tian Shan Mountains (2065 m) & $44-48^{\circ} \mathrm{N}, 92-93^{\circ} \mathrm{E}$ \\
\hline P. sulaki sp.n. & $\sigma^{\top}+t$ & Dzhungarian Alatau (2900-3000 m) & $45^{\circ} \mathrm{N}, 79^{\circ} \mathrm{E}$ \\
\hline P. susamyr & $\sigma^{2} Q_{1}$ & Tian Shan Mountains $(3000 \mathrm{~m})$ & $42^{\circ} \mathrm{N}, 72-74^{\circ} \mathrm{E}$ \\
\hline P. terskei & $q$ & Tian Shan Mountains $(2500 \mathrm{~m})$ & $42^{\circ} \mathrm{N}, 78^{\circ} \mathrm{E}$ \\
\hline P. tronovorum sp.n. & $\sigma^{\top} Q_{1}$ & Altai Mountains $(3300-3700 \mathrm{~m})$ & $48^{\circ} \mathrm{N}, 93^{\circ} \mathrm{E}$ \\
\hline P. tyshchenkoi & $\sigma^{2}+$ & $\begin{array}{l}\text { Upper Kolyma Upland, Tuva (900-1200 m), Chita } \\
\text { Oblast (1700-1800 m) }\end{array}$ & $50-63^{\circ} \mathrm{N}, 93-150^{\circ} \mathrm{E}$ \\
\hline P. vakhanski & $\sigma^{7}$ & Pamir $(4400 \mathrm{~m})$ & $37^{\circ} \mathrm{N}, 74^{\circ} \mathrm{E}$ \\
\hline P. volynkini & $\sigma^{2}+$ & Altai Mountains $(1800-1960 \mathrm{~m})$ & $51^{\circ} \mathrm{N}, 83^{\circ} \mathrm{E}$ \\
\hline
\end{tabular}




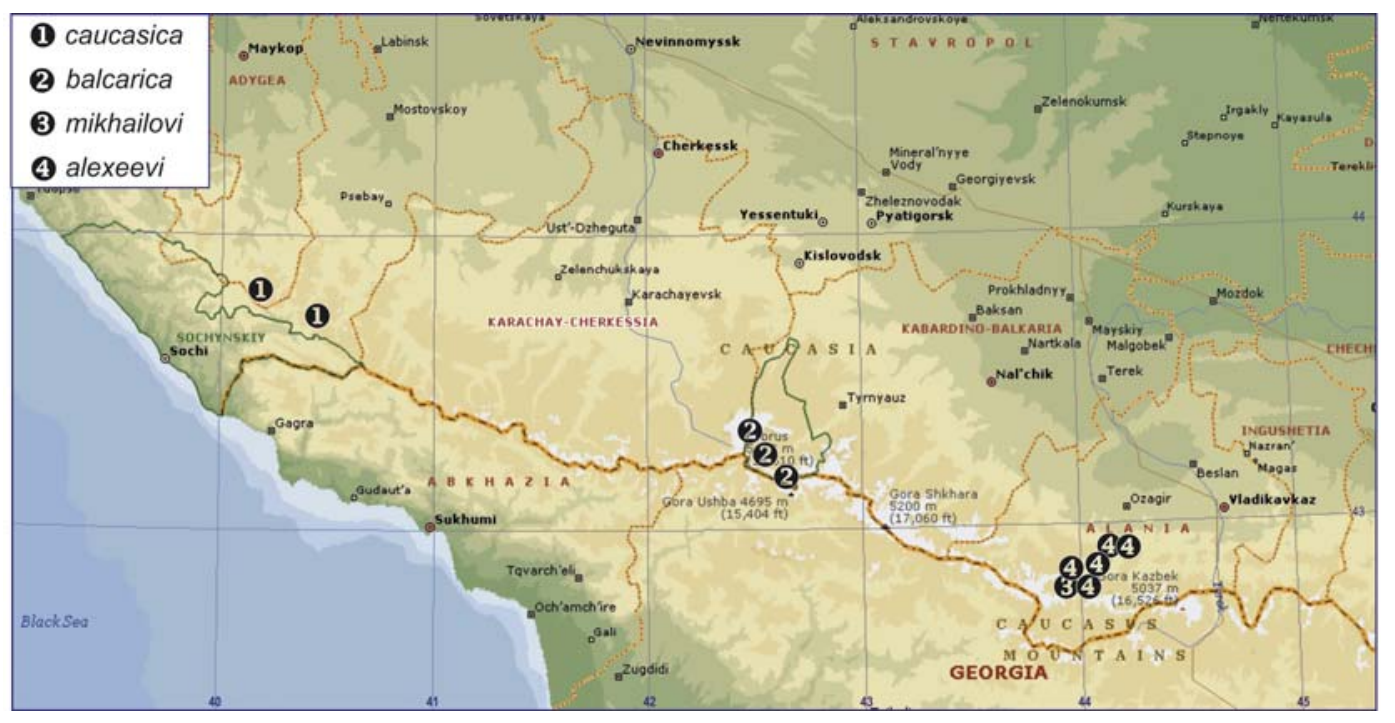

Map 3. Distribution records of the Parasyrisca potanini-group in the Caucasus.

Карта 3. Находки видов группы Parasyrisca potanini на Кавказе.

ern Cisokhotia $\left(150^{\circ} \mathrm{E}\right)$. A single species, $P$. orites, occurs in a small area of the Western Nearctic in the Coast and Cascade Mountains of southwestern British Columbia and northwestern Washington. Whereas the longitudinal gradient of the range of the potanini-group is somewhat smaller than in the vinosa-group, it has the widest latitudinal range: from $35^{\circ} \mathrm{N}$ to $63^{\circ} \mathrm{N}$ (Map 2).

Currently all of the records for the potanini-group in the Caucasus are from within Russia in the western part of the Caucasus Major (Map 3).

Like the vinosa- and guseripli-groups, the potani$n i$-group has a strongly disjunct range (Map 2): the Caucasus, the mountains of Central Asia, adjacent regions of Russia and China, Northeastern Siberia and northwestern North America. Probably the range of the potanini-group is continuous in Siberia and the apparent disjunction is caused by a lack of knowledge. There are four centers of species diversity within the range of the potanini-group: the Altai ( 7 endemic species of 11 known from the region), Pamir (5/6), Caucasus (4/4), and Tian Shan Mountains (3/6).

There are several large mountain ranges and upland areas which are suitable for Parasyrisca but where no specimens have yet been found. Among them are the Stanovoy Uplands, the Western and Eastern Sayan Mountains, the Saur and Tarbagatai Mountain Ranges, the Hindu Kush Mountains, the Iranian Plateau, and the Himalayas. Serious spider inventory work in those regions in the future likely will reveal more new species of Parasyrisca.

\section{ACKNOWLEDGEMENTS}

We thank R.V. Yakovlev, A.I. Shmakov, A.N. Cherepanov, A. Korablin, T.M. Krugova, A.E. Naidenov, A.S. Slepen'kov (all from Barnaul, Russia), H. Sulak (Munich, Germany), L. Stoppel' (Taldykorgan, Kazakhstan), U. Beket (Bayan-Ölgii, Mongolia) for organizing the expeditions to Altai, Kazakhstan, and
Mongolia during which the material treated in this paper was collected. We are grateful to Seppo Koponen (Zoological Museum, University of Turku) for providing museum facilities as well as to Mykola M. Kovblyuk (Simferopol, Ukraine) and an anonymous reviewer for commenting our manuscript. English of an earlier draft was kindly checked by Robb Bennett (Victoria, British Columbia).

\section{References}

Fomichev A.A. 2015. On the spider fauna (Arachnida: Aranei) of the Altai Republic (Russia) // Acta Arachnologica. Vol.64. No.2. P.63-70.

Fomichev A.A. 2016. New data on the spiders (Arachnida: Aranei) from Altai Territory, Russia // Arthropoda Selecta. Vol.25. No.1. P.119-126.

Marusik Yu.M., Ballarin F., Omelko M.M., Koponen S. 2014. On new and interesting records of spiders from northern Pakistan and India (Aranei) // Arthropoda Selecta. Vol.23. No.4. P.415424.

Marusik Yu.M., Fomichev A.A. 2010. A new species of Parasyrisca Schenkel, 1963 (Araneae, Gnaphosidae) from the Altai // Zootaxa. Vol.2626. P.65-68.

Marusik Yu.M., Fomichev A.A. 2016. A survey of East Palaearctic Gnaphosidae (Araneae). 7. Review of the Parasyrisca vinosagroup // Biological Bulletin of Bogdan Chmelnitskiy Melitopol State Pedagogical University. Vol.6. No.2. P.110-118.

Ovtsharenko V.I., Marusik Yu.M. 1988. [Spiders of the family Gnaphosidae (Aranei) of the north-east of the USSR (the Magadan Province)] // Entomologicheskoe Obozrenie. Vol.67. No.1. P.204-217 [in Russian, with English summary].

Ovtsharenko V.I., Marusik Yu.M. 1996. [Additional data on the spiders of the family Gnaphosidae (Aranei) of the north-east Asia] // Entomologicheskie issledovaniya na Severo-Vostoke SSSR. Vladivostok (1991). P.114-130 [in Russian].

Ovtsharenko V.I., Platnick N.I., Marusik Yu.M. 1995. A review of the Holarctic ground spider genus Parasyrisca (Araneae, Gnaphosidae) // American Museum Novitates. No.3147. P.1-55.

World Spider Catalog. 2017. World Spider Catalog. Version 18.5. Natural History Museum Bern, online at http://wsc.nmbe.ch (accessed on October, 2017).

Responsible editor K.G. Mikhailov 